\title{
Foreign Direct Investment: A Feature Key Drive's for India's Growth in it Sector
}

\author{
M. Kanaga, K. Uthayasuriyan
}

\begin{abstract}
The IT sector continues the main drivers of development in India, contributing nearly 72 percentage of its added gross value in 2017-18. However, this sector's growth in 2017-18 was moderate to 8.2 percent compared to 9.7 percent in the past year, although it remains greater than the IT sector, a main driver in FDI is frequently found in the open economy, a growth in investment assumes significant against the backdrop of widening current account deficit and trade deficit the country's current account deficit is likely touch 2.8 percent of GDP 2018-19 on the IT sector, has increased its contribution to India has been rapidly moving upwards on the technology adoptions curve to improve and deliver leading it has excelled in business developing innovative solution and collaborating larger firms to meet the current needs of the IT sector. which offers a qualified workforce and excellent growth prospects for investors compared to tightly regulated in Foreign Direct Investment, perhaps it needs not only capital investment, but as well as technology. It could be included that the analyzed trend values are preferred to FDI inflows in IT Sector.
\end{abstract}

Keywords : FDI, Feature Key, IT Sector, GDP.

\section{INTRODUCTION}

Foreign Direct Investment is an investment produced by a company or person in a nation of business interest situated in a growing nation in India. FDI is regulated under foreign fund inflows in April-June 2017-18 stood at USD 10.4 billion. FDI is growing by 23 percent to USD 12.75 billion during the April-June quarter of 2018-2019 in India. Globalization has been the world, and all nations are liberalizing their policies to welcome investments from nations that are abundant in capital assets. Foreign Direct Investment (FDI) in the evolving markers has become a battleground. The goal behind enabling FDI is to complement and supplement national investment by offering the greater level of economic development and possibilities for technological upgrading as well as worldwide management abilities and procedures. The international fund flows from the information shown in April-June 2018-2019. Singapore was the biggest source of FDI in 2018-2019 with USD 6.5 billion, followed by Mauritius (USD 1.5 billion), Japan (USD 874 million), the Netherlands (USD 836 million), the United Kingdom (USD 648 million), and the United States (USD 348 million). Growth in foreign investment takes on meaning in the context of widening current account deficit and trade deficit. The present account deficit in the country is probable to affect $2.8 \%$ of GDP in 2018-2019.

Revised Manuscript Received on September 25, 2019

Ms. M. Kanaga Ph.D (Full Time Research Scholar), Department of International Business Alagappa University, Karaikudi.

Dr. K. Uthayasuriyan Professor and Head, Department of International Business Alagappa University, Karaikudi.

\section{REVIEW OF LITERATURE}

Yilmaz Bayar (2018) in their study titled on "Foreign Direct Investment Inflows And Financial Development In Central And Eastern European Union Countries: A Panel Cointegration And Causality", Foreign Direct Investment (FDI) inflows in the globalized globe have risen significantly since the mid-1980s. The primary goal of this study is to evaluate relationships with panel data analysis between FDI inflows and the growth of the financial industry in Central and Eastern European Union countries from 1996 to 2015. Our findings show that there is no co-integrating connection between FDI inflows, foreign portfolio investments, and financial sector development, but there is a one-way causality from financial sector development to short-term FDI inflows.

Anil Duggal (2017) The Investment is very essential to an economy's development and prosperity. Equally crucial are domestic investment and foreign investment. Domestic investment can lead to domestic savings, consumption, and job creation. Foreign investment can reduce the savings gap at home. The study's primary goal is to examine foreign direct investment trends and patterns in India. For a research purpose, the descriptive design was adopted. Secondary data were used. ANOVA, average, proportion, and CAGR statistical instruments were implemented. Data were the collected from 2005 to 2017 . The general RBI automatic path is discovered contributing to the complete FDI inflow with a peak share of 64.98 percent.

Ratan Kirti (2016) In the age of development homogenization around the globe, "FDI Impact On Employment Generation And GDP Growth In India”, capital has become a vital element and a significant issue for nations, particularly developing ones. For this, the inflow of foreign funds has become one of the main assets. Countries are in a steady race to attract more international fund inflows or FDI. The aim of this article is to explore the effect of FDI in India on job creation capacity and GDP development, as well as attempting to correlate GDP development with employment trends, going through sector-specific FDI inflows in India and analyzing its ability to create jobs and productivity in India.

Abaukaka Thomas Onimisi (2014) has made a research on "Foreign Direct Investments and Employment Generation Nexus in Nigeria" The relationship between foreign direct investment and job generation in Nigeria using various linear information regression model covering the 2002-2012 period In order to define the connection empirically, some factors are integrated into the econometric system, including the Employment Level 1 (100-published annual

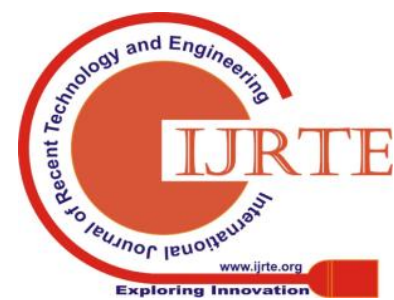


unemployment rate). Review) as the dependent variable whereas the explanatory variables are FDI (proportion of the nominal value of FDI in Nbn), GDP (annual GDP growth rate) and the nominal interest rate the study recommends, inter alia, that the government establish a mechanism by which the research should be conducted.

Bhavya Malhotra (2014) presented an entitled "Foreign Direct Investment: Impact On Indian Economy", The initiation of globalization, over the previous two centuries, developing nations, especially those in Asia, have witnessed an enormous increase in FDI inflows. While India was a latecomer to the FDI scene relative to other East Asian nations, its significant market potential and a liberalized policy system maintained its attractiveness as a good location for foreign investors. This research paper seeks to examine the effect of FDI on the Indian economy, especially after two decades of economic reforms, and analyzes the difficulties of taking a favorable stance in the worldwide FDI market. In addition to drawing attention to the complexities of interpreting FDI data in India, the paper provides the major policy implications of this analysis.

Syed Azhar, K.N.Marimuthu (2012) It is also focuses on the determinants and needs of FDI "An Overview of Foreign Direct Investment in India", annual assessment, oral sect analysis and FDI sources and reasons. Increasing investments in the form of foreign direct investment is one of the financial elements of globalization. Most nations have not been able to attract investment in latest times owing to the global recession. Even during the crisis era, India was able to achieve better FDIs than the developed countries. The FDI in India has been following a favorable growth rate in latest years in particular. The government has been focusing on policy liberalization since 1991 to welcome foreign direct investment.

\section{OBJECTIVES OF THE STUDY}

- To study the FDI Feature Key in IT Sector.

- To study the country- wise FDI inflows in IT Sector.

\section{KEY FEATURES OF FOREIGN DIRECT INVESTMENT}

$>$ Foreign Direct Investment needs not only investment in capital, but also leadership and technology. It improves the target company's productive ability as it includes physical asset development.

$>$ Compared to tightly controlled economies, it is frequently produced in open economies that offer a qualified workforce and excellent growth opportunities for investors.
$>$ It includes a long-term dedication, since there is no intention of seeking rapid capital gains.

$>$ As per Economic Cooperation and Development Organization, overseas investment of 10 percent above is regarded FDI.

$>$ Foreign direct investment needs not only investment in capital, but also leadership and technology.

$>$ Increase the target company's productive ability as it includes the development of physical resources, contributing to job creation possibilities and rapid economic growth in the cost nation. Establish effective control of the investment in the company.

$>$ The investment firm has a significant impact on the company's decision-making process in which the investment is produced.

$>$ It represents a significant dedication to resources they both involves local activities and presences. Companies invest in nations with particular comparative benefits.

$>$ Direct investors address specific social and cultural factors in the host industry more intensively.

India has moved quickly up the technology adoption curve to innovate and offer major company distribution services, and has served as one of the most appealing offshore distribution centers among other countries. It also serves as a hub for start-ups to develop innovative alternatives and collaborate with bigger companies to satisfy present requirements. The IT sector's present focus is on the use of artificial intelligence and could enable service with an enhanced need for actuation, while the business years are anticipated to be threatened by reducing human resource demand in the industry.

Table 1:FDI INFLOWS IN IT SECTOR IN INDIA

\begin{tabular}{|c|c|c|}
\hline Year & FDI Inflows & $\begin{array}{c}\text { Trend (Inflows } \\
\text { in FDI) US\$ } \\
\text { Million }\end{array}$ \\
\hline $2013-14$ & 934 & 1651.2 \\
\hline $2014-15$ & 2154 & 2077.3 \\
\hline $2015-16$ & 4319 & 2503.4 \\
\hline $2016-17$ & 1937 & 2929.5 \\
\hline $2017-18$ & 3173 & 3355.6 \\
\hline
\end{tabular}

Source: Computed

The table 1 shows that the Trend Analysis (Inflow) of IT Sectors for the year 2013-14 to 2017-18 in Mauritius. It is clear from the table 2017-18 contributes the major trend value inflows with 3355.6 million followed by $2016-17$ in 2929.5 million. The least trend value of inflows is 2013-14 in 1651.2 million. 


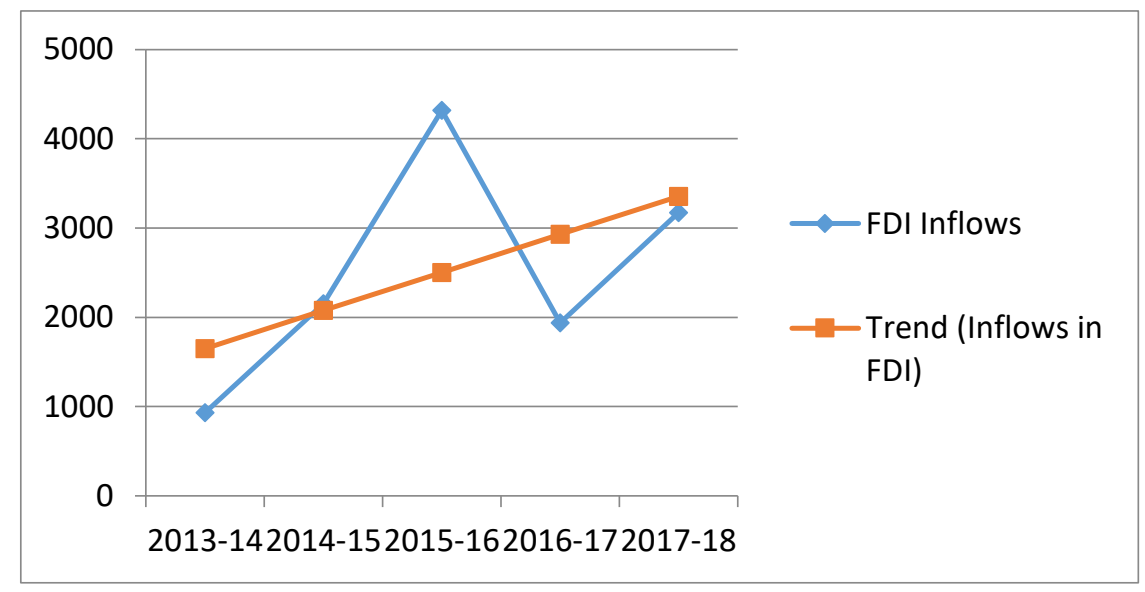

Figure 1:FDI INFLOWS IN IT SECTOR IN INDIA

The Figure 1.1 shows that the 2017-18 contributes the major trend value of IT Sectors inflow with 3355.6 million followed by 2016-17 with 2929.5 million. The least trend value of inflows is 2013-14 with 1651.2 million.

\section{COUNTRY -WISE FDI INFLOWS TREND} ANALYSIS OF IT SECTOR IN INDIA (2013-2018)

Table 2: TREND ANALYSIS OF IT SECTOR IN MAURITIUS

\begin{tabular}{|c|c|c|}
\hline Year & FDI Inflows & $\begin{array}{c}\text { Trend (Inflows } \\
\text { in FDI) US\$ } \\
\text { Million }\end{array}$ \\
\hline
\end{tabular}

\begin{tabular}{|c|c|c|}
\hline $2013-14$ & 3695 & 3375.6 \\
\hline $2014-15$ & 5878 & 6070.1 \\
\hline $2015-16$ & 7452 & 8764.6 \\
\hline $2016-17$ & 13383 & 11459.1 \\
\hline $2017-18$ & 13415 & 14153.6 \\
\hline
\end{tabular}

Sources: Computed

The table1.2 shows that the Trend Analysis (Inflow) of IT Sectors for the year 2013-2018 in Mauritius. It is clear from the table 2017-18 contributes the major trend Value inflows with 14153.6 million followed by 2016-17 11459.1million. The least trend value of inflows is 2013-14 3375.6 million.

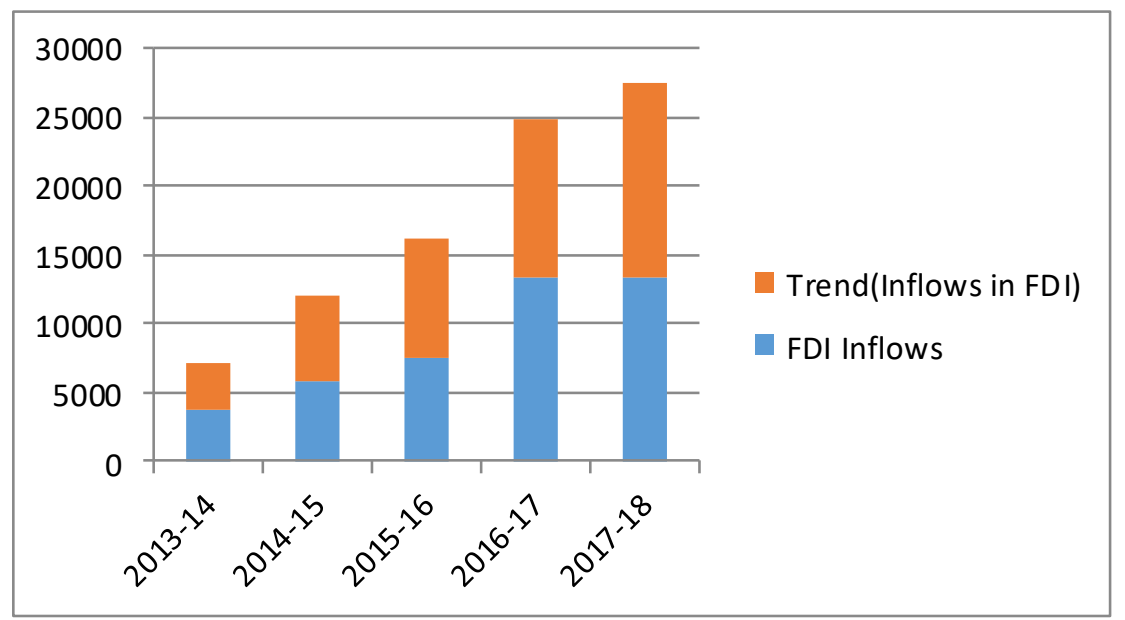

Figure 2:TREND ANALYSIS OF IT SECTOR IN MAURITIUS

The Figure 1.2 shows that the 2017-18 contributes the major trend value of IT Sectors inflow with 14153.6 million followed by 2016-17 with 11459.1 million. The least trend value of inflows is $2013-14$ with 3375.6 million.

Table 3: Trend Analysis Of It Sector In Singapore

\begin{tabular}{|c|c|c|}
\hline Year & FDI Inflows & $\begin{array}{c}\text { Trend (Inflows } \\
\text { in FDI) } \\
\text { US\$ Million }\end{array}$ \\
\hline $2013-14$ & 4415 & 5345 \\
\hline $2014-15$ & 5137 & 6455.8 \\
\hline
\end{tabular}

\begin{tabular}{|c|c|c|}
\hline $2015-16$ & 12479 & 7566.6 \\
\hline $2016-17$ & 6529 & 8677.4 \\
\hline $2017-18$ & 9273 & 9788.2 \\
\hline
\end{tabular}

The table1.3 shows that the Trend Analysis (Inflow) of IT Sectors for the year 2013-2018 in Mauritius. It is clear from the table 2017-18 contributes the major trend Value inflows with 9788.2 million followed by 2016-17 8677.4 million. The least trend value of inflows is 2013-14 5345 million. 


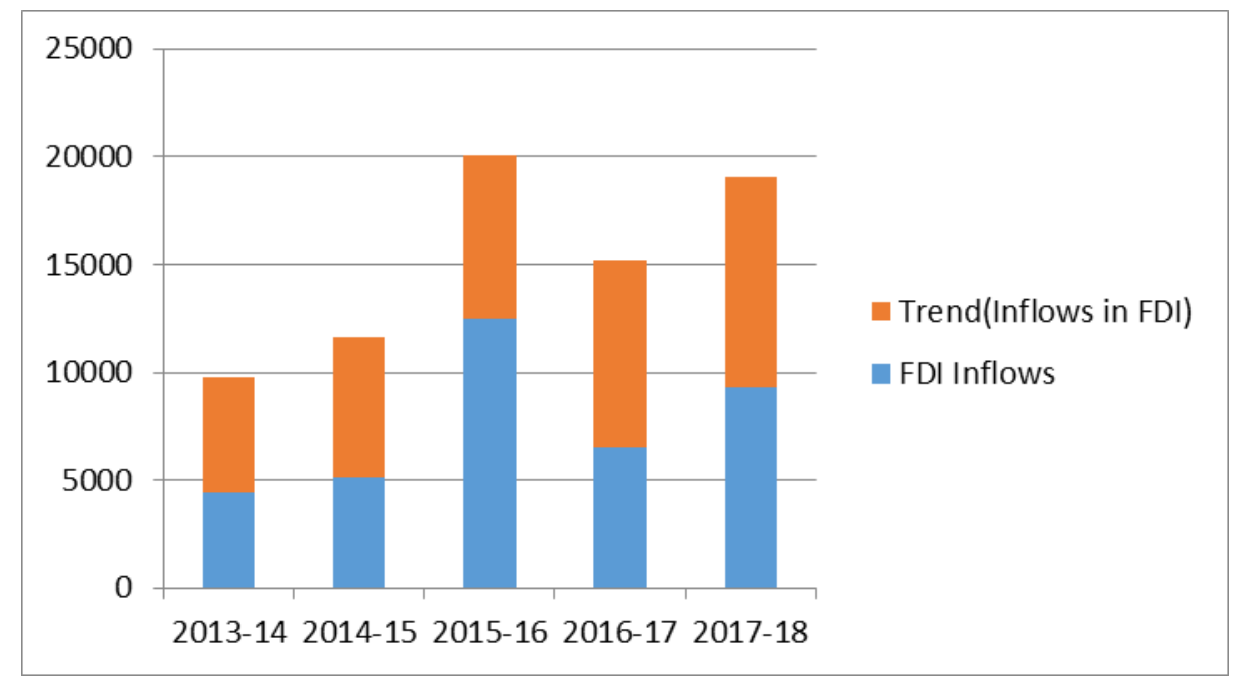

Figure 3: TREND ANALYSIS OF IT SECTOR IN SINGAPORE

The Figure 1.3 shows that the $2017-18$ contributes the major trend value of IT Sectors inflow with 9788.2 million followed by $2016-17$ with 8677.4 million. The least trend value of inflows is 2013-14 with 5345 million.

Table 4: TREND ANALYSIS OF IT SECTOR IN NETHERLAND

\begin{tabular}{|c|c|c|}
\hline Year & FDI Inflows & $\begin{array}{c}\text { Trend (Inflows } \\
\text { in FDI) } \\
\text { US\$ Million }\end{array}$ \\
\hline $2013-14$ & 1157 & 1486.4 \\
\hline $2014-15$ & 2154 & 1898.4 \\
\hline $2015-16$ & 2330 & 2310.4 \\
\hline $2016-17$ & 3234 & 2722.4 \\
\hline $2017-18$ & 2677 & 3134.4 \\
\hline
\end{tabular}

The table1.4 shows that the Trend Analysis (Inflow) of IT Sectors for the year 2013-2018 in Mauritius. It is clear from the table 2017-18 contributes the major trend Value inflows with 3134.4 followed by 2016-17 2722.4. The least trend value of inflows is 2013-14 1486 .

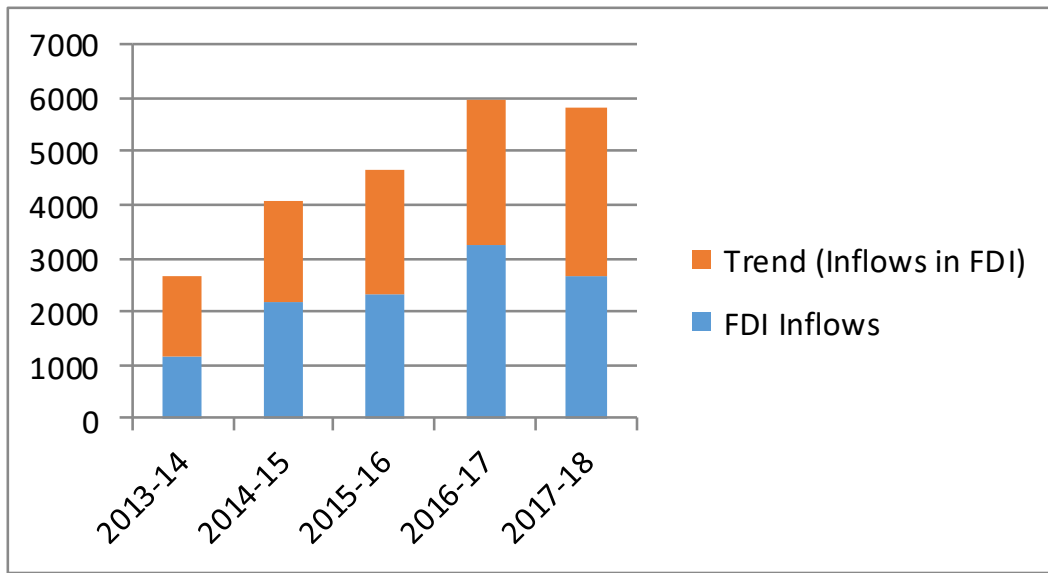

Figure 4:TREND ANALYSIS OF IT SECTOR IN NETHERLAND

The Figure 1.4 shows that the 2017-18 contributes the major trend value of IT Sectors inflow with 3134.4 million followed by $2016-17$ with 2722.4 million. The least trend value of inflows is $2013-14$ with 1486.4 million.

Table 5: TREND ANALYSIS OF IT SECTOR IN USA

\begin{tabular}{|c|c|c|}
\hline Year & FDI Inflows & $\begin{array}{c}\text { Trend (Inflows } \\
\text { in FDI) } \\
\text { US\$ Million }\end{array}$ \\
\hline $2013-14$ & 617 & 1592.8 \\
\hline
\end{tabular}

\begin{tabular}{|l|l|l|}
\hline $2014-15$ & 1981 & 1879.7 \\
\hline $2015-16$ & 4124 & 2166.6 \\
\hline $2016-17$ & 2138 & 2453.5 \\
\hline $2017-18$ & 1973 & 2740.4 \\
\hline
\end{tabular}

The table1.5 shows that the Trend Analysis (Inflow) of IT Sectors for the year 2013-2018 in Mauritius. It is clear from the table 2017-18 contributes the major trend Value inflows with 2740.4 million followed by $2016-17$ in 2453.5 million. The least trend value of inflows is 2013-14 1592.8 million. 


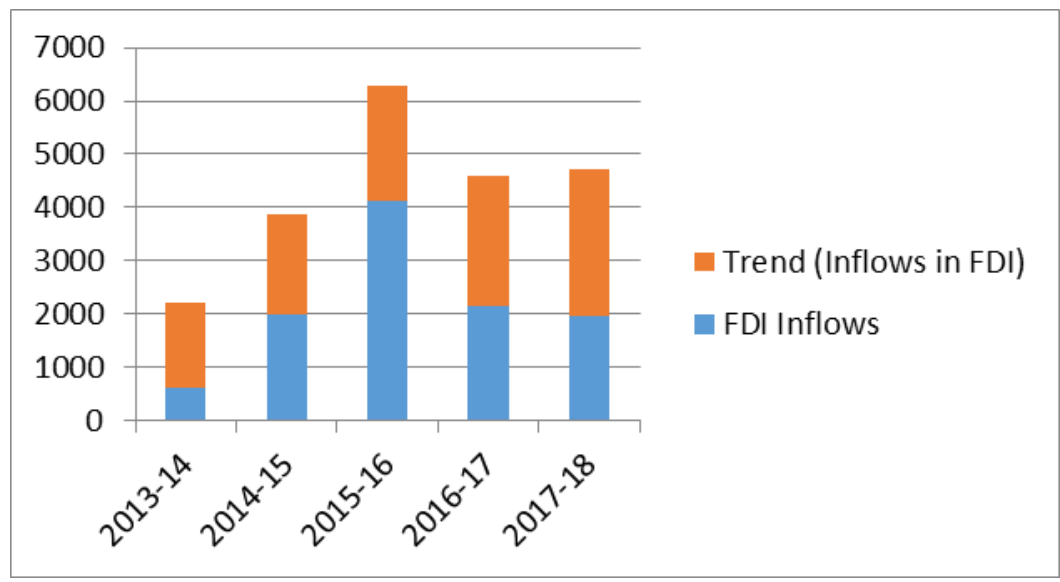

Figure 5: TREND ANALYSIS OF IT SECTOR IN USA

The Figure 1.5 shows that the 2017-18 contributes the major trend value of IT Sectors inflow with 3134.4 million followed by 2016-17 with 2453.5 million. The least trend value of inflows is 2013-14 with 1592.8 million.

Table 6:TREND ANALYSIS OF IT SECTOR IN JAPAN

\begin{tabular}{|c|c|c|}
\hline Year & FDI Inflows & $\begin{array}{c}\text { Trend (Inflows } \\
\text { in FDI) } \\
\text { US\$ Million }\end{array}$ \\
\hline $2013-14$ & 1795 & 1985.6 \\
\hline $2014-15$ & 2019 & 2111 \\
\hline
\end{tabular}

\begin{tabular}{|l|l|l|}
\hline $2015-16$ & 1818 & 2236.4 \\
\hline $2016-17$ & 4237 & 2361.8 \\
\hline $2017-18$ & 1313 & 2487.2 \\
\hline
\end{tabular}

Source: Computed

The table1.6 shows that the Trend Analysis (Inflow) of IT Sectors for the year 2013-2018 in Mauritius. It is clear from the table 2017-18 contributes the major trend Value inflows with 2487.2 million followed by 2016-17 2361.8 million. The least trend value of inflows is 2013-14 1985.6 million.

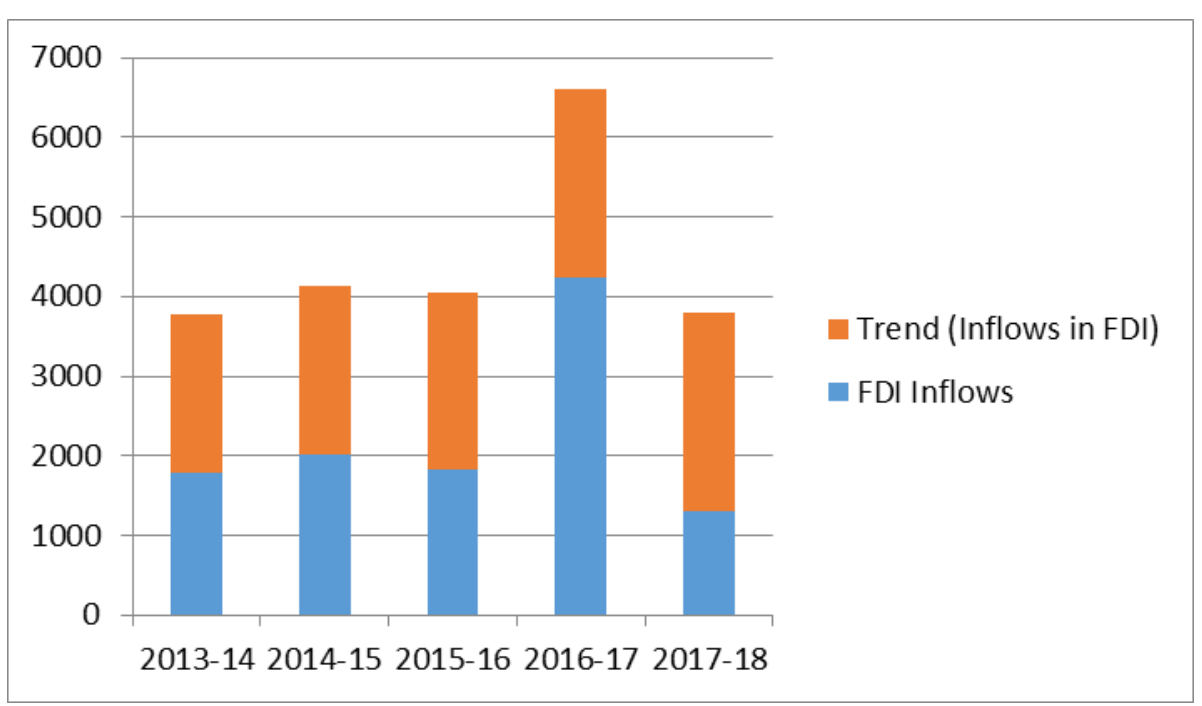

Figure 6:TREND ANALYSIS OF IT SECTOR IN JAPAN

The Figure 1.6 shows that the 2017-18 contributes the major trend value of IT Sectors inflow with 2487 million followed by 2016-17 with 2361.8 million. The least trend value of inflows is 2013-14 with 1985.6 million.

\section{CONCLUSION}

This article focuses on descriptive elements of FDI inflows over the past five years performance of IT sector in India. India was one of the developing countries and even during the recession was able to demonstrate favorable GDP development. It has done well in comparison, then the FDI trend value. India has all the factors such as good infrastructure, prospective markets, abundant labor, natural resource accessibility, and finally the financial and commercial policies that favored FDI. The government should formulate measures that could attract more foreign investment in the manufacturing sector than in the IT sector. India's FDI policy has liberalized to make the market more attractive to investors. Today, all international bodies, including the IT Sector, regularly rank the nation among the top three worldwide investment locations.

\section{REFERENCES}

1. Syed azhar, K.N.marimuthu, "AN OVERVIEW OF FOREIGN DIRECT INVESTMENT IN INDIA", EXCEL International Journal of Multidisciplinary Management Studies Vol.2 Issue 1, January 2012, ISSN 22498834

2. Ratan Kirti1, "FDI IMPACT ON EMPLOYMENT GENERATION 
AND GDP GROWTH IN INDIA" Asian Journal of Economics and Empirical Research ISSN: 2409-2622 Vol. 3, No. 1, 40-48, 2016.

3. Abaukaka Thomas Onimisi, "FOREIGN DIRECT INVESTMENTS AND EMPLOYMENT GENERATION NEXUS IN NIGERIA" Journal of Educational and Social Research MCSER Publishing, Rome-Italy, Vol. 4 No.5 July 2014.

4. Anil Duggal, "FOREIGN DIRECT INVESTMENT IN INDIA" Journal of Internet Banking and Commerce, December 2017, vol. 22, no. 3.

5. Bhavya Malhotra, "FOREIGN DIRECT INVESTMENT: IMPACT ON INDIAN ECONOMY", Global Journal of Business Management and Information Technology. ISSN 2278-3679 Volume 4, Number 1 (2014), pp. 17-23.

6. Yilmaz Bayar, "FOREIGN DIRECT INVESTMENT INflOWS AND FINANCIAL DEVELOPMENT IN CENTRAL AND EASTERN EUROPEAN UNION COUNTRIES: A PANEL COINTEGRATION AND CAUSALITY", International Journal of Financial Studies. Int. J. Financial Stud. 2018, 6, 55; doi:10.3390/ijfs6020055. 